\title{
The effect of compost made of sheep manure on the first cut of a semi-natural grassland
}

\author{
Daniel Díaz Fernández - István Csízi \\ University of Debrecen, Karcag Research Institute, Karcag, Hungary \\ danieldf@agr.unideb.hu
}

\begin{abstract}
SUMMARY
In an experiment, two types of compost were tested on natural grassland in order to improve the productivity of a natural sward on solonetz soil. Both composts were made of on-farm produced sheep manure, but the second one was enriched in phosphorus. These fertilizers/composts are officially authorized and can be applied in organic farming. Zero application and three rates of fertilizer were tested

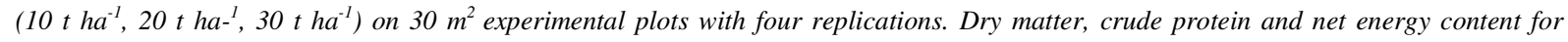
maintenance were measured and determined and their yields per unit area were calculated. We found that all the treated plots produced significantly higher yield than the control ones, and in some cases the yields were almost three times higher. However, the optimal compost dose varied, depending on the examined parameter. Based on the evaluation of the experiment results along with rainfall data, it was concluded that, with higher precipitation, the positive effect of the compost application was bigger. The difference between the natural and enriched compost is remarkable, but it has to be mentioned that even the natural compost showed good results; therefore, it is also effective in improving the fertility of grassland.
\end{abstract}

Keywords: grassland productivity, compost application, organic fertilizer, dry matter, crude protein

\section{INTRODUCTION}

European regulations, such as Natura 2000 and Agri-environment Schemes (AES) provide strict framework for grassland management. These regulations prohibit the application of manure and mineral fertilizers on natural grasslands, thus the nutrient recycling on grasslands depends on excretes from grazing animals. This situation results in a negative nutrient balance and low productivity on natural grasslands. Environmentalists in general have a fear that fertilizing natural and semi-natural grasslands will cause a decrease in diversity, but examining the species richness of grasslands participating in AES - de Sainte Marie (2014) mentioned that frequently and moderately manured areas showed better species diversity than those without fertilization. This means that, with reasonable nutrient management, grasslands can improve their productibility while preserving or even improving the biodiversity of the sward.

However, maintaining the balance between productibility and biodiversity is a crucial factor because the existence of many plant (Verrier and Kirkpatrick 2005, Chytrý et al. 2015) and animal (Swengel 1998, D'Aniello et al. 2011) species is determined by the conditions of grassland ecosystems. On the other hand, utilization causes degradation in soil productibility and nutrient management cannot be neglected under farm conditions. International endeavours show that organic fertilizers are going to have their renaissance soon. Lalor et al. (2012) stated that the sustainable application of organic fertilizers is getting more and more attention. In their experiment, Pozdíšek et al. (2008) experienced that, with organic fertilizer, the yield of grasslands can be improved.

Moreover, as the world population grows and meat and milk consumption increases, livestock production has to be adapted and developed (Thornton 2010, Saha and Butler 2017). Solution for that is to increase the harvestable forage per unit area. As grasslands cover $30 \%$ of the European agricultural land (Huyghe et al. 2014) their correct management is essential, also they have an important role in maintaining biodiversity and sustaining the rural communities and cultural heritage (Soussana and Lemaire 2014).

\section{MATERIAL AND METHODS}

The experiment started in 2015 on the grassland of the sheep farm of the Karcag Research Institute, University of Debrecen. The natural grasslands in the region on solonetz soil are rich in species (more than 40 species per hectare) and the dominant grasses are Festuca pseudovina and Alopecurus pratensis. The main goal of the experiment was to receive data about the effectiveness of two different types of compost, produced by the sheep farm, and made of sheep manure. The first was a natural compost (marked with $\mathrm{N}$ ), the second was enriched in phosphorus, with a minimum $1.9 \%$ DM of $\mathrm{P}_{2} \mathrm{O}_{5}$-content (marked with $\mathrm{E}$ ). Both composts are officially allowed in organic farming, and have a minimum $\mathrm{N}$-content of $2.5 \% \mathrm{DM}$.

Three rates of compost $\left(10 \mathrm{t} \mathrm{ha}^{-1}, 20 \mathrm{t} \mathrm{ha}^{-1}, 30 \mathrm{t} \mathrm{ha}^{-1}\right)$ were tested on $3 \mathrm{~m} \mathrm{X} 10 \mathrm{~m}$ experimental plots in four replications. Treatments included four control plots too (marked with Z). We measured the fresh yield of each plots and took laboratory samples from them. The laboratory investigations included dry matter (DM) content, crude protein (CP) content and net energy used for maintenance $\left(\mathrm{NE}_{\mathrm{m}}\right)$ and were carried out by standard methods. Harvests were made at the end of May and at the beginning of September. This time the results from the first harvests are presented in this paper.

Data on daily rainfall were recorded locally by the research institute. 


\section{RESULTS AND DISCUSSION}

\section{Precipitation}

It is known that the decomposition and the utilization of organic fertilizers are highly dependent on moisture conditions on grasslands. The first growth of the grassland is determined by the precipitation during winter and spring. Experimental years were different regarding available moisture for grassland growth. Spring of 2015 and 2017 had relatively less rainfall compared to 2016, which had remarkably more rainfall through the period of the primary growth (Figure 1).

Figure 1: Accumulated precipitation between $1^{\text {st }}$ of January and $31^{\text {st }}$ of May during the three examined years

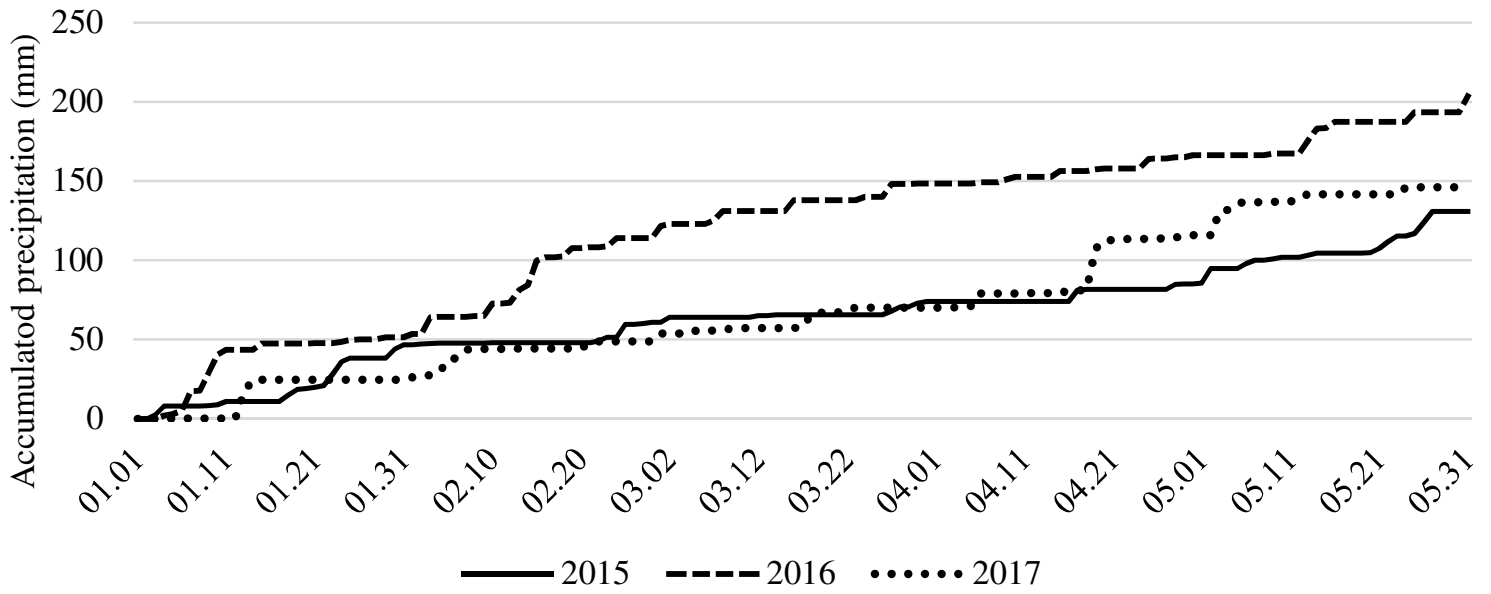

Source: Karcag Research Institute, local measurements

\section{DM production}

As a result of unfavourable weather conditions, the yield of grasslands in 2015 was low due to the lack of precipitation. Data from that year do not show any correlation between compost application and DM yield. The applied organic fertilizer probably had no time to decompose and the plants could not benefit from the nutrient application. The favourable weather in 2016, which was rich in precipitation, resulted in significantly higher DM production due to the compost applications (Figure 2).

It can be seen that in the second year that each rates and both kinds of compost caused significant increase in DM production. Some differences between the effectiveness of the rates can be seen, but in most cases it is not significant. On average, the E30 treatment produced $3.69 \mathrm{t} \mathrm{ha}^{-1}$ dry matter and the E10 and E20 treatments produced $3.19 \mathrm{t} \mathrm{ha}^{-1}$. It cannot be stated that the E30 was more effective, thanks to the high standard deviation.

Based on the obtained results, it can be said that the difference between the two composts is very remarkable. With the $30 \mathrm{t} \mathrm{ha}^{-1}$ dose of the enriched compost the grassland could produce more forage than the N30 one by $1 \mathrm{t} \mathrm{ha}^{-1} \mathrm{DM}$. Considering the fact that the Hungarian mean DM production for the total grassland area is $1.5 \mathrm{t} \mathrm{ha}^{-1}$, the effectiveness of the natural compost can not be neglected either. The DM yield of $\mathrm{N} 20$ was $2.63 \mathrm{t} \mathrm{ha}^{-1}$ and that for N30 was 2.66 $\mathrm{t} \mathrm{ha}^{-1}$ which means that the plots treated with the natural compost could produce more than the control plots by $1 \mathrm{tha}^{-1}$.
In 2017 DM yield was expected higher than that in 2016, as the compost from previous years might provide better nutrient supply for grass growth, but as it can be seen the treatments were less effective in 2017 than in 2016. The only exception was the E30 treatment what could produce the same yield as like in previous year. It means that the higher rainfall in 2016 had very positive effect on the utilization of fertilizer and due to the less favourable weather conditions in 2017 the plants could not utilize the nutrients from the compost. However the tendency of yield increase was the same, as all the treated plots produced more forage than the control and the enriched compost was clearly more effective than the natural.

\section{CP production}

In 2015 the compost application could not affect the crude protein yield (Figure 3). Results from 2016 show that the plots treated with compost had higher CP yield (NZ: $130.84 \mathrm{~kg} \mathrm{ha}^{-1}$; EZ: $161.18 \mathrm{~kg} \mathrm{ha}^{-1}$ ) than the control plots. As like with dry matter production, the differences between $\mathrm{CP}$ productions were not significant statistically, due to the high standard deviation.

The only exception was the E20 treatment, which produced most protein $\left(381.17 \mathrm{~kg} \mathrm{ha}^{-1}\right)$. It was followed by E30 (316.99 $\left.\mathrm{kg} \mathrm{ha}^{-1}\right)$. As like for the dry matter production, there was not significant difference between the two types of composts in crude protein yield. The crude protein yields of N10, N20, N30 and E10 treatments were close to each other and even E30 could not produce significantly higher $\mathrm{CP}$ yield than 
the mentioned treatments. In 2017 N30 could produce more than other $\mathrm{N}$ doses in the same year, but could not exceed the results of previous year. With 286.22 $\mathrm{kg} \mathrm{ha}^{-1} \mathrm{~N} 30$ could produce the same as N20 (289.33 $\left.\mathrm{kg} \mathrm{ha}^{-1}\right)$ and N30 (276.41 kg ha $\left.{ }^{-1}\right)$ in 2016. The E30 treatment in 2017 could exceed its result from previous year, but other plots treated with enriched compost produced the same or less as in 2016. Thanks to the less rainfall in 2017 the abundance of leguminous plants were lower than it was in 2016. During the three-year period, the E30 treatment of 2017 could produce the most CP (391.54 kg ha ${ }^{-1}$ ), despite of the fact, that 2016 had better weather conditions. The differences between N30, E10 and E20 are not significant.

Figure 2: The average DM yield of the treatments

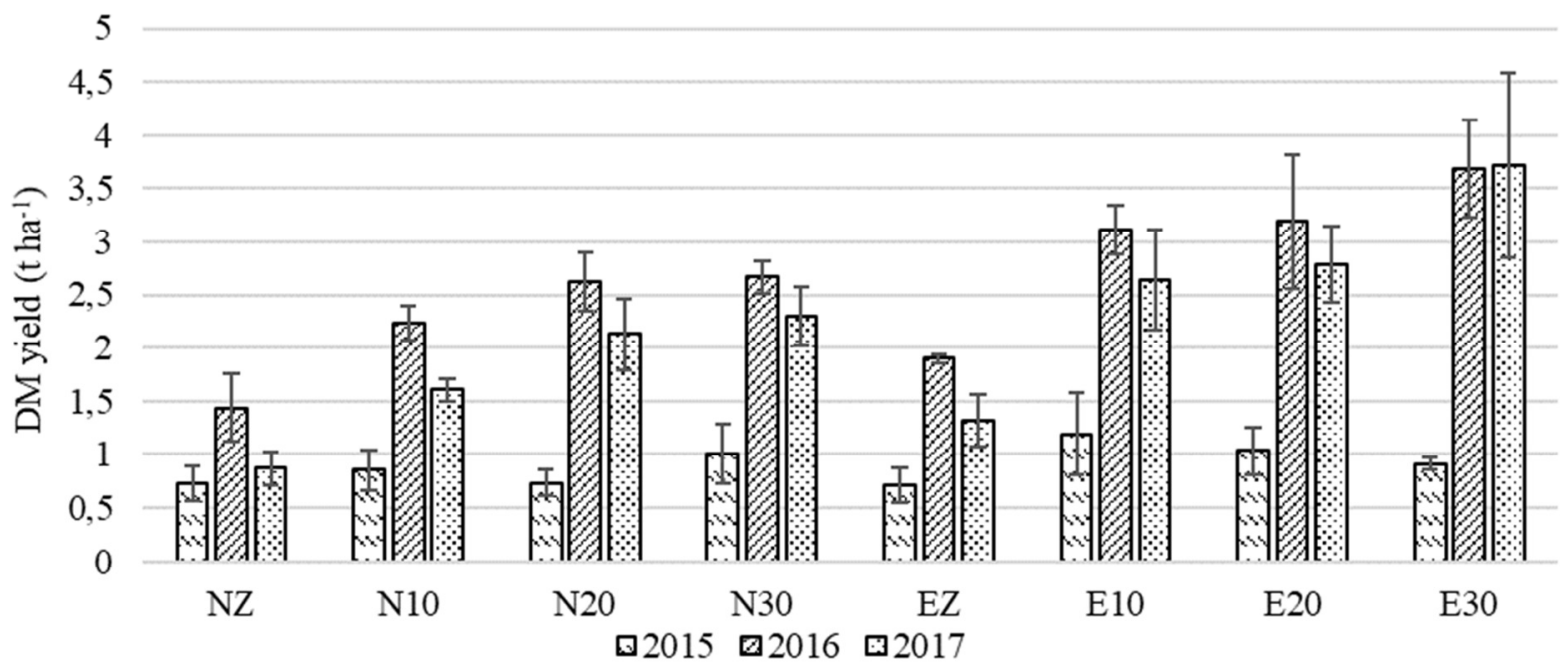

Figure 3: The average CP yield of the treatments

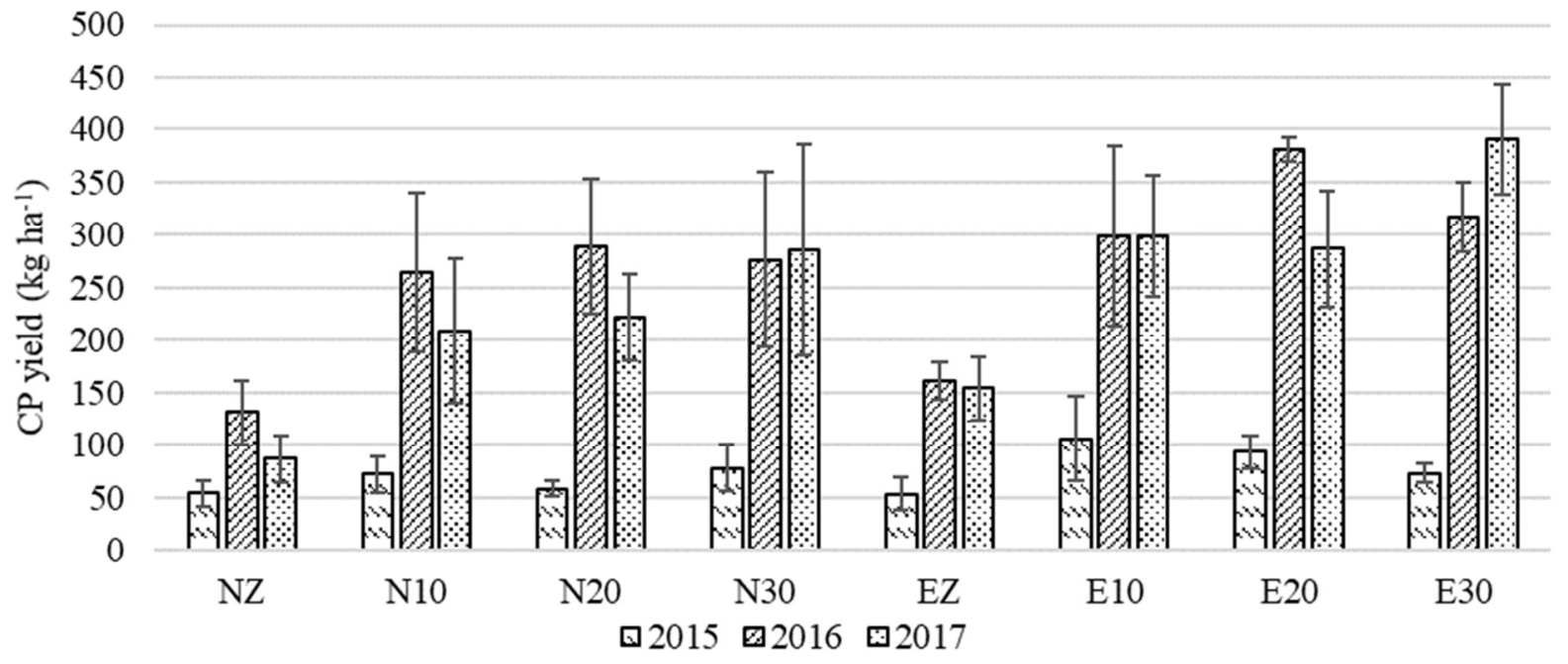

\section{$\mathrm{NE}_{\mathrm{m}}$ production}

Similarly to the DM yield and CP yield, in 2015, the compost application did not have influence on the $\mathrm{NE}_{\mathrm{m}}$ production either. But evaluating the data it was clear that in 2016, the treated plots showed a significant better $\mathrm{NE}_{\mathrm{m}}$ yield than the control ones (Figure 4). With $20546.46 \mathrm{MJ} \mathrm{ha}^{-1}$ the E30 treatment could double the yield of the control plots. The difference between the $\mathrm{N}$ and $\mathrm{E}$ compost is remarkable, but the differences between the effectiveness of the treatments are not significant. E10 and E20 treatment had almost the same $\mathrm{NE}_{\mathrm{m}}$ yield, 17149.56 $\mathrm{MJ} \mathrm{ha}^{-1}$ and 17887.37 $\mathrm{MJ} \mathrm{ha}^{-1}$ respectively, whereas N20 and N30 produced 14665.44 MJ ha ${ }^{-1}$ and 14675.19 $\mathrm{MJ} \mathrm{ha}^{-1}$, respectively.

As it was experienced with the DM yields as well, in 2017 all the treatments underperformed, only the E30 could produce the same yield as it did in 2016 . The tendency of $\mathrm{NE}_{\mathrm{m}}$ responses of compost treatments is similar to the DM yield responses. 
Experimental results presented show that application of both types of compost can be effective in increasing the quantity and quality of the yield of the grassland. However the enriched compost could perform better than the natural one. For each examined parameters the effects of enriched compost treatments exceeded the effects of natural compost treatments. With the highest rate of compost we could almost triple the yield of some parameters. It was also found that moisture relations enlarge the effectiveness of organic fertilization. The year 2016 with its higher rainfall produced better yields than 2017, but it seems that with E30 treatment we could compensate the effects of moisture deficiency. It means compost treatment could be a solution to decrease the negative effect of drought and to increase production safety.

Figure 4: The average $\mathbf{N E}_{\mathbf{m}}$ yield of the treatments

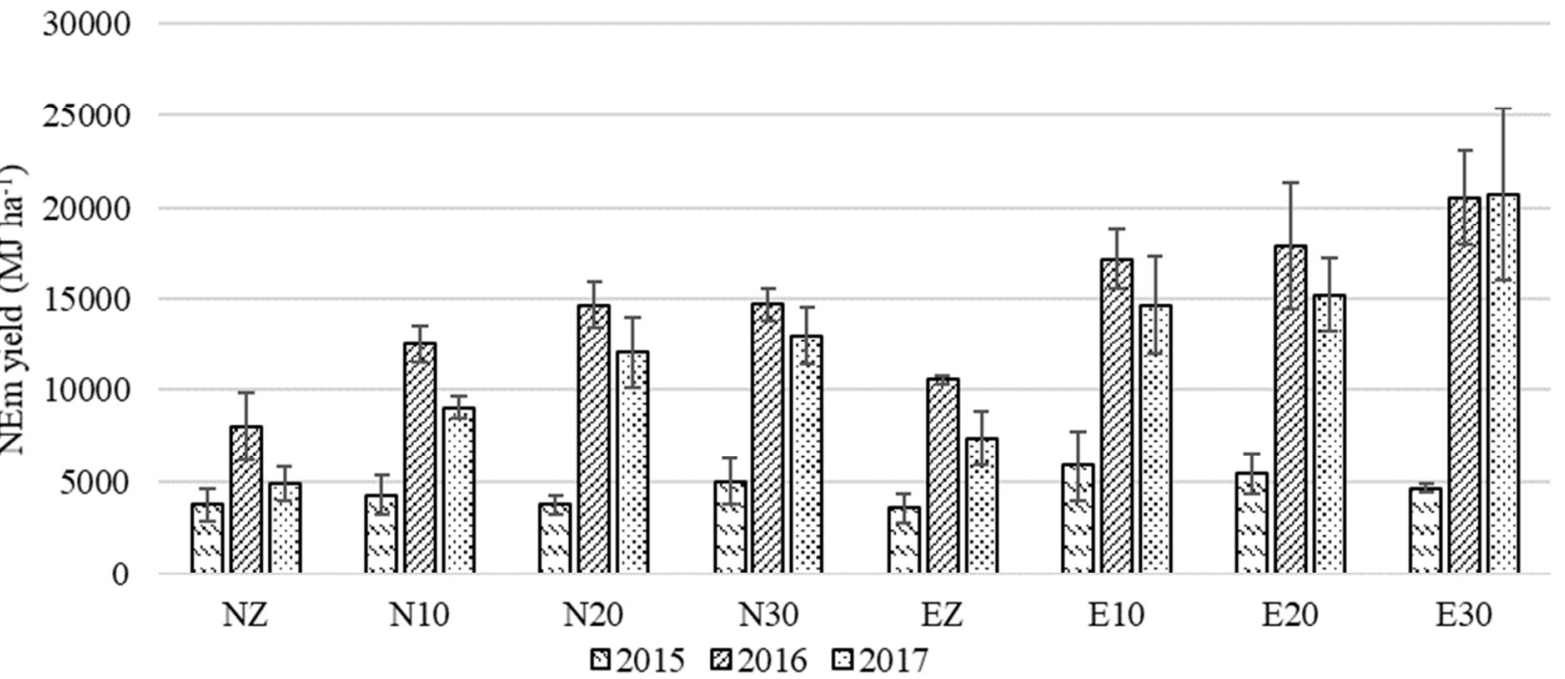

\section{CONCLUSIONS}

As productivity of Hungarian natural grasslands are very low, an increasing number of researchers state fertilization is a necessary process to increase production. Based on our results, one can say that application of tested composts is a proper solution for increasing the yield of grasslands under unfavorable soil and climatic conditions. In spite of the fact that compost cannot be cultivated into the grassland soils, it may still improve the fertility of the soil; however, it took more time to exert its effect. With the application of compost, one can produce more and better forage on grasslands under marginal conditions. As these composts are allowed in organic farming as well, their correct application meets guidelines of sustainable farming, thus the growth of the yield does not involve any negative effects on nature. As compost application uses on-farm generated materials, these organic fertilizers also fit better in the nutrient cycle of a certain farm.

\section{ACKNOWLEDGEMENTS}

The work/publication is supported by the EFOP3.6.3-VEKOP-16-2017-00008 project. The project is co-financed by the European Union and the European Social Fund.

\section{REFERENCES}

Christine de Sainte Marie (2014): Rethinking agri-environmental schemes. A result-oriented approach to the management of species-rich grasslands in France. Journal of Environmental Planning and Management. 57: 704-719.

Chytrý, M.-Dražil, T.-Hájek, M.-Kalníková, V.-Preislerová, Z.Šibík, J.-Ujházy, K.-Xmanová, I.-Bernátová, D.-Blanár, D.Dančák, M.-Dřevojan, P.-Fajmon, K.-Galvánek, D.-Hájková, P.-Herben, T.-Hrivnák, R.-Janeček, Š.-Janišova, M.-Jiráská, S.-Kliment, J.-Kochjarová, J.-Lepš, J.-Leskovjanská, A.Merunková, K.-Mládek, J.-Skezák, M.-Šeffer, J.-Šefferová, V.-Škodová, I.-Uhlírová, J.-Ujházyová, M.-Vymazalová, M. (2015): The most species-rich plant communities in the Czech republic and Slovakia (with new world records). Preslia. 8: $217-278$.
D'Aniello, B.-Stanislao, I.-Bonelli, S.-Balletto, E. (2011): Haying and grazing effects on the butterfly communities of two Mediterranean-area grasslands, Biodiversity and Conservation. 20: 1731-1744.

Huyghe, C.-De Vliegher, A.-van Gils, B.-Peeters, A. (2014): Grasslands and herbivore production in Europe and effects of common policies. Versailles. Éditions Quae.

Lalor, S. T. J.-Hoekstra, N. J.-Murphy, P. N. C.-Richards, K. G.Lanigan, G. J. (2012): Practical advice for slurry application strategies for grassland systems. Proceedings of the International Fertiliser Society. 
Pozdíšek, J.-Štýbnarová, M.-Kohoutek, A.-Svizolová, M.-Ržonca, J. (2008): Forage quality by animal fertilizer applications and by different grassland management. Grassland Science in Europe. 13: 498-500.

Soussana, J. F.-Lemaire, G. (2014): Coupling carbon and nitrogen cycles for environmentally sustainable intensification of grasslands and crop livestock systems. Agricultrure, Ecosystem \& Environment. 190: 9-17.

Swengel, A. B. (1998): Effects of management of butterfly abundance in tallgrass prairie and pine barrens. Biological Conservation. 83: 77-89.
Thornton, P. K. (2010): Livestock production: recent trends, future prospects. Philosophical Transactions of the Royal Society B: Biological Sciences. 365: 2835-2867.

Verrier, F. J.-Kirkpatrick, J. B. (2005): Frequent mowing is better than grazing for the conservation value of lowland tussock at Pontville, Tasmania. Austral Ecology. 30: 74-78. 